\title{
Maize-Dwelling Insects Omnivory in Spodoptera frugiperda (J.E. Smith) (Lepidoptera: Noctuidae) Egg Masses
}

\author{
Alexandre Carlos Menezes-Netto*, Andrea Corrêa Varella and Odair Aparecido \\ Fernandes \\ Departamento de Fitossanidade; Faculdade de Ciências Agrárias e Veterinárias; Universidade Estadual Paulista \\ Júlio de Mesquita Filho; Rod. Paulo Donato Castellane, km 5; 14884-900; Jaboticabal - SP - Brasil
}

\begin{abstract}
This work reports the first record of omnivory behavior of Diabrotica speciosa (Coleoptera, Chrysomelidae), Leptoglossus zonatus (Hemiptera, Coreidae), Monocrepidius aff. posticus and Monocrepidius fuscofasciatus (Coleoptera, Elateridae) on fall armyworm Spodoptera frugiperda (Lepidoptera, Noctuidae) egg masses in maize fields. Macrophotography was used to record the activity of these insects on fall armyworm sentinel egg masses during 2009 and 2010 maize growing seasons. The presence of omnivorous insects changes the species population dynamics within the ecosystem. Therefore, the implications of these interactions should be understood and taken into consideration for integrated pest management enhancement.
\end{abstract}

Key words: Facultative predator, phytozoophagy, predation

\section{INTRODUCTION}

The knowledge of multi-trophic interactions between species that live in agricultural habitats is indispensable for the successful utilization of integrated pest management practices. Some herbivorous species, over the evolutionary process, developed a few morpho-physiological and behavioral features that allowed them to act both as phytophagous and predator, known as omnivory (Pimm and Lawton 1978). This feeding habit is largely spread in many insect species (Coll and Guershon 2002). Hypothesis to explain the mechanisms underlying this feeding ability have been studied. For example, enzymatic complexes have been suggested as a mechanism that permit predatory hemipterans switch between plant and animal food sources (see review by Torres and Boyd 2009).
In agroecosystems, omnivorous insects may be important biological control agents, because they can sustain high population levels even when prey densities are low (Karban et al. 1994). However, when omnivorous insects act as herbivores, they may become pests (Coll and Guershon 2002). The alternation between pest and predatory status may be a function of prey availability (Rosenheim et al. 2004) or quality of the host plant (Coll 1996).

Here we report the occurrence of omnivory behavior of maize-dwelling arthropods on Spodoptera frugiperda egg masses as a contribution for better understanding the multitrophic interactions in maize.

Observations on the natural biological control agents of $S$. frugiperda (fall armyworm) in maize fields were performed during the dry and wet seasons in 2009 and 2010. Two experiments per season were performed. Hybrid maize (Dow

*Author for correspondence: alexandrecmn@gmail.com 
2B688, Dow Agrosciences) plants were artificially and randomly infested with 80 sentinel egg masses $(<24 \mathrm{~h})$ in a $3000 \mathrm{~m}^{2}$ total area. Egg masses were obtained from the laboratory and were stapled in the newly emerged whorl leaf. Experiments were conducted during early to midwhorl stage. Natural mortality factors were observed in eight 2-h-long diurnal and nocturnal observations during three days after infestation. Insects associated to the egg masses were photographed and collected for identification.

Recognized predators of S. frugiperda, as Doru luteipes Sccuder, 1876 (Dermaptera, Forficulidae), Harmonia axyridis (Pallas, 1773), and Eriopis connexa (Germar, 1824) (Coleoptera, Coccinelidae) were observed feeding on the egg masses. However, predatory action of Diabrotica speciosa (Germar, 1824) (Coleoptera, Chrysomelidae), Leptoglossus zonatus (Dallas, 1852) (Hemiptera, Coreidae), Monocrepidius aff. posticus (Eschscholtz, 1822) and Monocrepidius fuscofasciatus (Eschscholtz, 1829) (Coleoptera, Elateridae) was also observed in all the eight experiments.

D. speciosa, known as corn rootworm, is characterized by its polyphagous habit and multivoltine life cycle (Cabrera Walsh 2003). In Brazil, the occurrence of $D$. speciosa is widely reported in many different crops (Zucchi et al. 1993). In maize fields, Ventura and Gomes (2004) associated the population growth of this pest with the expansion of cultivated areas during the dry season. Corn rootworm larvae feed on the root of the plants and cause death of newly germinated plants and/or deformation of developing plants (Pinto et al. 2004). Adults feed on pollen, flowers, and leaves of the plants. Injury on the leaves of young maize plants are very similar to that caused by the fall armyworm. This might mislead the diagnostic in the field (Cruz et al. 1997; Roberto et al. 2001; Ávila and Milanez 2004). Other Diabrotica species from temperate regions also present similar feeding habits (Branson and Krysan 1981; Elliott et al. 1990). However, during our field observations, adults of D. speciosa were often seen preying on eggs of S. frugiperda (Fig. 1a-f) and this was the first record of omnivory of this species in a maize agroecosystem. It was also noted that $D$. speciosa adults may consume all eggs of an egg mass.

Adults of $L$. zonatus were also recorded preying on fall armyworm eggs (Fig. 1g-i), despite the recognized phytophagous habit of this species
(Panizzi 1989; Fernandes and Grazia 1992; Mitchell 2000). In maize fields in Brazil, Panizzi (1989) reported that these insects could cause economic damage. The adults and nymphs of $L$. zonatus are sucking insects and feed on immature grains, causing wilt, death and, therefore, losses in seed production (Pinto et al. 2004). In the family Coreidae, the usage of different feeding sources by the herbivores has already been reported for at least another five genera (Adler and Wheeler Jr. 1984). For this species, this was also the first record of occurrence of omnivorous behavior in Brazilian maize fields.

Two species of Elateridae, Monocrepidius aff. posticus (Fig. 1j-k) and M. fuscofasciatus (Fig. 11), also fed on eggs of $S$. frugiperda. Such occurrence could be biased because Monocrepidius spp. predation activity was exclusively recorded during the nocturnal observations, when it was more difficult to register their presence. There is little information on the biology of neotropical species of Elateridae (Cruz et al. 1997; Cruz 2008; Vanin et al. 2008). It is known that the larvae of these insects, including the species of the genus Monocrepidius, are root and stem borers and adults feed on the leaves, buds, pollen, and nectar (Lima 1953). Studies of the biology (Norris Jr. 1957), behavior and rearing (Dobrovsky 1954), distribution and abundance (Stone 1975; Willis et al. 2010) of North American species report exclusively herbivory of larvae and adults of these beetles. Denux and Zagatti (2010) reviewed exotic species in Europe and Conoderus posticus (Eschscholtz, 1822) was pointed out as a phytophagous invasive species in Portugal and Azores. All these studies showed that the adults of Elateridae have similar feeding habits. This was the first record of the consumption of preys as part of the diet of $M$. aff. posticus and $M$. fuscofasciatus in maize crops of Brazil. These Elateridae species were observed in 5\% of the 86 predatory events recorded. Thus, it was less frequent than $D$. speciosa and $L$. zonatus which were observed $21 \%$ and $17 \%$, respectively.

Complex interactions found in the ecological systems that include omnivores interfere on the dynamics, resources utilization, and demography of several other populations within a community. In agricultural systems, the presence of omnivores may have positive (e.g., enhance predator pool diversity) or negative consequences (e.g., omnivorous insect chooses feeding on the plant material) (Hunter 2009). Thus, planning integrated 
pest management programs can become more complex in the ecological systems that include omnivorous.

Therefore, the present observations highlighted the necessity of detailed studies to quantify the frequency of predation, predatory capacity, factors that trigger the choice of food source, as well as the importance of each food source (Rosenheim et al. 2004) to understand the real impact of these omnivorous insects in maize ecosystems and its implication on enhancement of integrated pest management.
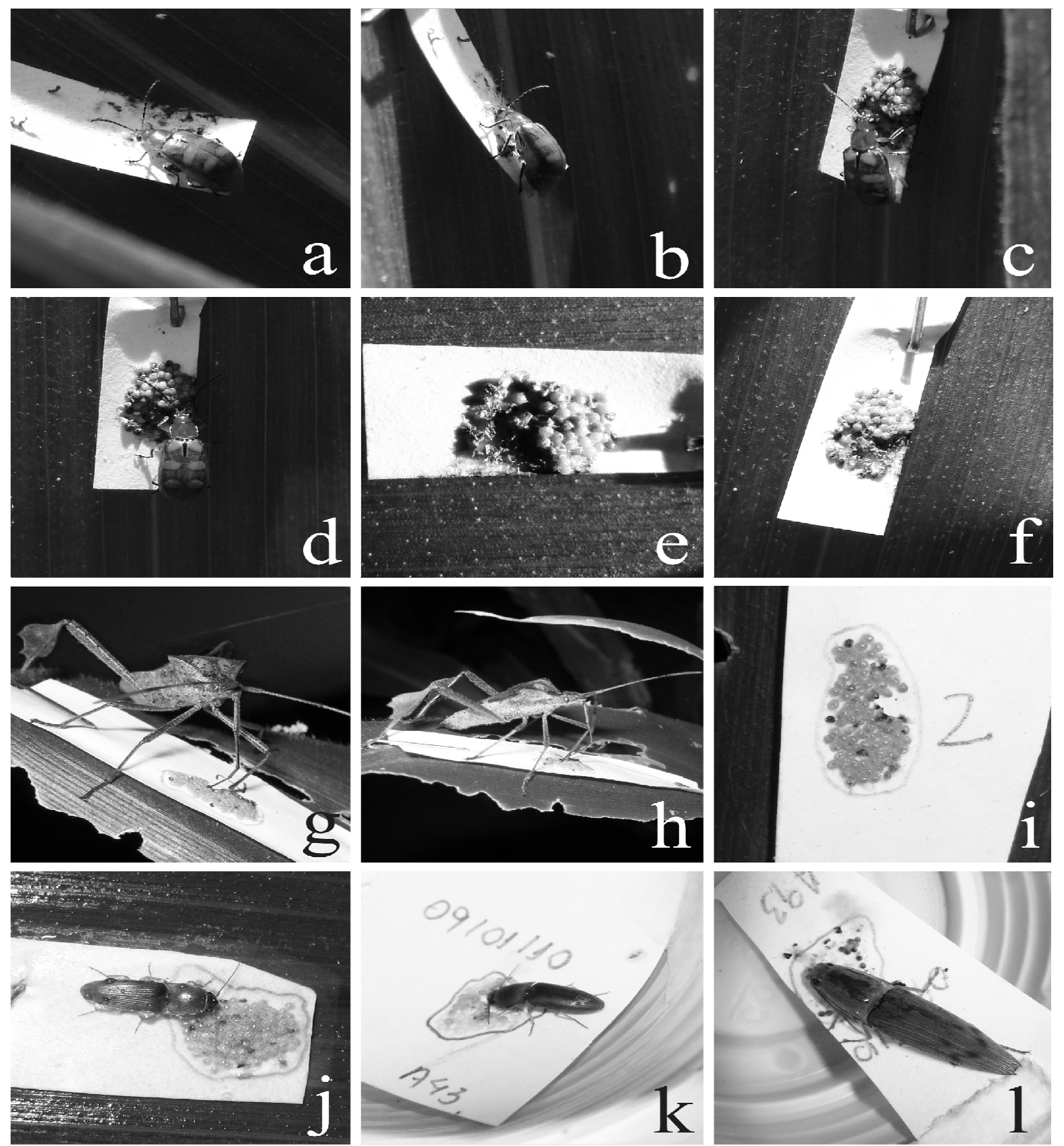

Figure 1- Fall armyworm eggs predation by omnivorous insects on maize plants (a-d. Diabrotica speciosa; e-f. D. speciosa injury on fall armyworm egg mass; g-h. Leptoglossus zonatus; i. L. zonatus injury on fall armyworm egg mass; j-k. Monocrepidius aff. posticus; 1. M. fuscofasciatus). 


\section{ACKNOWLEDGEMENTS}

The authors thank CNPq for the grant to the first author. We are also grateful to Daniel F. Caixeta for essential help on field work and for the pictures of L. zonatus; to Tiago R. Lohmann for invaluable help during field work; to Juliana D. S. Alonso for revision of the manuscript. Also, we thank Drs. Javier J. L. Manchego (Servicio Nacional de Sanidad Agraria, Lima, Peru), Luciano de A. Moura (Universidade Federal do Rio Grande do Sul), José A. M. Fernandes (Universidade Federal do Pará), and Simone P. Rosa (Museu de Zoologia da Universidade de São Paulo) for the identification of $D$. luteipes, D. speciosa, $L$. zonatus, and $M$. aff. posticus and $M$. fuscofasciatus, respectively.

\section{REFERENCES}

Adler PH, Wheeler Jr. AG. Extra-phytophagous food source of Hemiptera-Heteroptera: Bird droppings, dung, and carrion. J Kans Entomol Soc. 1984; 57: 21-27.

Ávila CJ, Milanez JM. Larva-alfinete. In: Salvadori JR, Ávila CJ, Silva MTB, editors. Pragas de solo no Brasil. Passo Fundo: Embrapa Trigo; 2004. p. 345-378.

Branson TF, Krysan JL. Feeding and oviposition behavior and life cycle strategies of Diabrotica: an evolutionary view with implications for pest management. Environ Entomol. 1981; 10: 826-831.

Cabrera Walsh G. Host range and reproductive traits of Diabrotica speciosa (Germar) and Diabrotica viridula (F.) (Coleoptera: Chrysomelidae), two species of South American pest rootworms, with notes on other species of diabroticina. Environ Entomol. 2003; 32: 276-285.

Coll M. Feeding and ovipositing on plants by an omnivorous insect predator. Oecol. 1996; 105: 214-220.

Coll M, Guershon M. Omnivory in terrestrial arthropods: mixing plant and prey diets. Annu Rev Entomol. 2002; 47: 267-297.

Cruz I. Manejo de pragas da cultura do milho. In: Galvão JCC, Miranda GV, editors. Tecnologias de produção no milho: economia, cultivares, biotecnologia, $2^{\mathrm{a}}$ safra, adubação, quimigação, doenças, plantas daninhas e pragas. Viçosa: Editora UFV; 2008. p. 311-366.

Cruz I, Valicente FH, Santos JP, Waquil JM, Viana PA. Manual de identificação de pragas da cultura do milho. Sete Lagoas: Embrapa Milho e Sorgo; 1997.

Denux O, Zagatti P. Coleoptera families other than Cerambycidae, Curculionidae sensu lato, Chrysomelidae sensu lato and Coccinelidae. BioRisk. 2010; 4: 315-406.

Dobrovsky TM. Laboratory observations on Conoderus vagus Candeze (Coleoptera, Elateridae). Fla Entomol. 1954; 37: 123-131.

Elliott NC, Gustin RD, Hanson SL. Influence of adult diet on the reproductive biology and survival of the western corn rootworm, Diabrotica virgifera virgifera. Entomol Exp Appl. 1990; 56: 15-21.

Fernandes JAM, Grazia J. Estudo dos estágios imaturos de Leptoglossus zonatus (Dallas, 1852) (Heteroptera: Coreidae). An Soc Entomol Bras. 1992; 21: 179-188.

Hunter MD. Trophic promiscuity, intraguild predation and the problem of omnivores. Agric For Entomol. 2009; 11: 125-131.

Karban R, Hougen-Eitzmann D, English-Loeb G. Predator-mediated apparent competition between two herbivores that feed on grapevines. Oecol. 1994; 97: 508-511.

Lima AC. Insetos do Brasil. Coleópteros, Parte 2, Vol. 8. Rio de Janeiro: Escola Nacional de Agronomia; 1953.

Mitchell PL. Leaf-footed bugs (Coreidae). In: Schaefer CW, Panizzi AR, editors. Heteroptera of economic importance. Boca Raton: CRC Press; 2000. p. 337-403.

Norris Jr. DM. Bionomics of the southern potato wireworm, Conoderus falli Lane. 1. Life history in Florida. Fla Agric Exp Stn Annu Rep. 1957; 660: 109111.

Panizzi AR. Desempenho de ninfas e adultos de Leptoglossus zonatus Dallas (Hemiptera: Coreidae) em diferentes alimentos. An Soc Entomol Bras. 1989; 18: 375-389.

Pimm SL, Lawton JH. On feeding on more than one trophic level. Nature 1978; 275: 542-544.

Pinto AS, Parra JRP, Oliveira HN. Guia ilustrado de pragas e insetos benéficos do milho e sorgo. Ribeirão Preto: A. S. Pinto; 2004.

Roberto SR, Genta W, Ventura UM. Diabrotica speciosa (Ger.) (Coleoptera: Chrysomelidae): New pest in table grape orchards. Neotrop Entomol. 2001; 30: 721-722.

Rosenheim JA, Goeriz RE, Thacher EF. Omnivore or herbivore? Field observations of foraging by Lygus Hesperus (Hemiptera: Miridae). Environ Entomol. 2004; 33: 1362-1370.

Stone MW. Distribution of four introduced Conoderus species in California (Coleoptera: Elateridae). Coleopt Bull. 1975; 29: 163-166.

Torres JB, Boyd DW. Zoophytophagy in predatory Hemiptera. Braz Arch Biol Technol. 2009; 52: 11991208.

Vanin SA, Ramos CS, Guimarães EF, Kato MJ. Insect feeding preferences on Piperaceae species observed in São Paulo city, Brazil. Rev Bras Entomol. 2008; 52: 7277.

Ventura MU, Gomes MR. Population study of Diabrotica speciosa (Ger.) (Coleoptera: Chrysomelidae) in fall/winter season. Ciência Rural 2004; 34: 1939-1943.

Willis RB, Abney MR, Kennedy GG. Survey of wireworms (Coleoptera: Elateridae) in North Carolina sweetpotato fields and seasonal abundance of Conoderus vespertinus. J Econ Entomol. 2010; 103: 1268-1276.

Zucchi RA, Silveira Neto S, Nakano O. Guia de identificação de pragas agrícolas. Piracicaba: Fundação de Estudos Agrários Luiz de Queiroz; 1993.

Received: November 23, 2010; Revised: April 28, 2011; Accepted: October 07, 2011. 